\title{
Achievements and Peculiarities in Studies of Ancient DNA and DNA from Complicated Forensic Specimens
}

\author{
A.P. Grigorenko1, 2,3, S.A. Borinskaya ${ }^{1}$, N.K. Yankovsky ${ }^{1}$, E.I. Rogaev 1,2,3* \\ ${ }^{1}$ Vavliov Institute of General Genetics, Russian Academy of Sciences \\ ${ }^{2}$ Research Center of Mental Health, Russian Academy of Medical Sciences \\ ${ }^{3}$ University of Massachusetts Medical School, Worcester, U.S.A. \\ *E-mail: rogaev@vigg.ru
}

\begin{abstract}
Studies of ancient DNA specimens started 25 years ago. At that time short mitochondrial DNA (mtDNA) fragments were the main targets in ancient DNA studies. The last three years were especially productive in the development of new methods of DNA purification and analysis. Complete mtDNA molecules and relatively large fragments of nuclear DNA are the targets of ancient DNA studies today. Ancient DNA studies allowed us to study organisms that went extinct more than ten thousand years ago, to reconstruct their phenotypic traits and evolution. Ancient DNA analyses can help understand the development of ancient human populations and how they migrated. A new evolutionary hypothesis and reconstruction of the biota history have been re-created from recent ancient DNA data. Some peculiarities and problems specific to the study of ancient DNA were revealed, such as very limited amounts of DNA available for study, the short length of the DNA fragments, breaks and chemical modifications in DNA molecules that result in "postmortem" mutations or complete blockage of DNA replication in vitro. The same specific features of DNA analysis were revealed for specimens from complicated forensic cases that result in the lack of experimental data or interpretation problems.

Here, we list the specific features of ancient DNA methodology and describe some achievements in fundamental and applied research of ancient DNA, including our own work in the field.

Keywords: ancient DNA, methods, evolution, DNA identification, forensic examination.

Abbreviations: mtDNA - mitochondrial DNA, cmtDNA - complete mtDNA sequence, STR - short tandem repeats.
\end{abstract}

\section{INTRODUCTION}

Ancient DNA studies allow to empirically verify evolutionary hypotheses and contribute to the complex reconstruction of historical changes in biota. The analysis of DNA from human archeological samples reveals information on the genetic traits of ancient inhabitants of various geographical regions.

The first published reports on the study of ancient DNA appeared 25 years ago. Researchers managed to extract a DNA fragment from a museum sample of dried muscle tissue taken from a quagga - a South-African odd-toed ungulate animal that disappeared in the $19^{\text {th }}$ century. The extracted DNA fragment was cloned in a phage vector and sequenced. Phylogenetic analysis showed that the determined sequence of the mitochondrial DNA (mtDNA) was related to zebra species $[1,2]$. The next study described the extraction, cloning, and sequencing of DNA fragment from a $\sim 2,400$-thousandyear-old Egyptian mummy [3]. After these, attempts were made to extract DNA from the remains of animals, plants and microorganisms whose ages ranged from several hundreds to more than a million years (see review in [4]). As the data accumulated, it became clear that the age of the remains that could still have analyzable templates, calculated using kinetics of DNA decay, was not greater than 0.1-1.0 Myr, and that the level of DNA preservation depended on the age and type of the biological sample, and also on the conditions in which it was preserved [5, 6]. Reports on the extraction of DNA from specimens older than 1 Myr are most probably erroneous. The most ancient authentic DNA samples have been isolated from permafrost specimens, such as mammoth, bison and other animal remains, chloroplast DNA from plants, and bacterial DNA [7-12]. Fragments up to 900-1 000 base pairs (bp) have been amplified from these samples. The low temperature and humidity improve DNA preservation, that allows researchers to analyze samples from remains that are tens of thousands of years old (Fig. 1) [13].

Studies of DNA isolated from ancient or historic specimens must deal with a number of methodical problems. These include the exceedingly small quantity and small size of the DNA fragments extracted from ancient samples, as well as the presence of chemical DNA modifications that block DNA replication and cause the appearance of postmortem mutations in the nucleotide sequence. Spontaneous damage of DNA molecules in a living cell is repaired during replication or causes death and elimination. After an organism dies, both the reparation and elimination of cells with damaged DNA come to a halt; that leads to the accumulation of chemical modifications and fragmentation of DNA molecules. Furthermore, the DNA is further destroyed by the organisms of the soil biota. Degradation of ancient DNA makes contamination of the samples by even a single molecule of modern DNA a major cause of false results.

Using the PCR techniques [14-16] has considerably widened the possibilities of ancient DNA analysis, since it allows in vitro amplification of a single original DNA molecule. PCR allows selective amplification of target DNA fragments; that is very important in ancient DNA analysis, since $99 \%$ of the 


$\begin{array}{lllll}1 & 2 & 3 & 4 & M\end{array}$
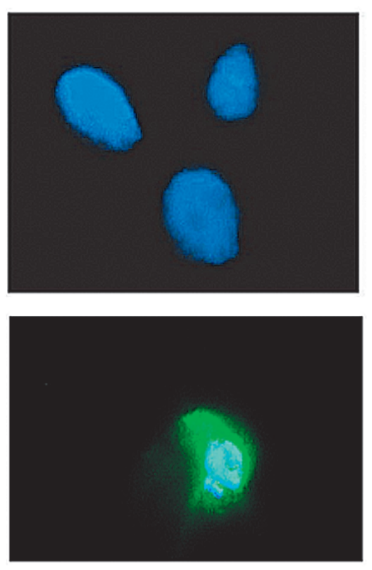

a

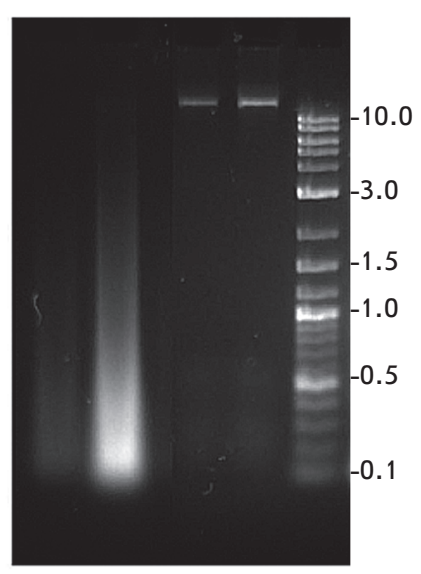

b

Fig. 1. Unusually well-preserved mammoth $M$. primigenius DNA specimen obtained from permafrost-preserved remains found in 1986 in the valley of the Enmynveem River (Chukotka):

a - Fluorescence of nuclei in muscle cells of $M$. primigenius $(\sim 33,000$ years old) after DAPI staining indicates a relatively high degree of DNA preservation; $b$ - electrophoresis of total genomic DNA extracted from mammoth muscle tissue (lane 1 is 1/10 dilution of the DNA on lane 2), and control DNA isolated from fresh human blood samples (lanes 3 and 4). The right lane is a DNA molecular weight marker (fragments sizes are indicated in $\mathrm{kb}$ ) [13]

extracted DNA can be a mixture of bacterial or fungal DNA from soil.

The development of extraction and sequencing technologies in ancient DNA study in the past few years has allowed to sequence the complete mitochondrial genomes, to reconstruct nuclear genomic regions, to analyze the genetic population variety of extinct species (moa, mammoth, furry rhinoceros, cave bear, Beringian bison, giant eagle, Neanderthal, etc.), and to study changes in the Pleistocene and Holocene ecosystems (see reviews [4, 17-20]).

Years of research have resulted in the establishment of a number of requirements to ancient DNA studies and criteria upon which the authenticity of resulting data is judged. Contamination of the analyzed samples by modern DNA is still one of the most pressing problems during ancient DNA analysis. One of the well-known examples is the report related to the extraction of a DNA fragment from the dinosaur bone [21] that, as it turned out during further analysis, was a fragment of human nuclear DNA [22], as well as the mentioned above attempt to sequence DNA from an Egyptian mummy [3]. Currently, the sequence obtained in the mummy study is assumed to be the result of modern human DNA contamination $[17,23]$.

DNA sequences reconstructed from ancient or historic samples can also contain errors because of hydrolytic or oxidative modification of the ancient DNA. For example, sequencing of long regions of the same sample of Neanderthal nuclear DNA was performed by two groups of researchers. The Edward Rubin group from the Joint Genome Institute

of the U.S. Department of Energy published a 65,000 bp sequence, and the Svante Pääbo group from the Max Planck Institute for Evolutionary Anthropology reported the sequencing of 1 million bp [24, 25]. Further data analysis determined that a considerable amount of errors was present in the second group's data. Most of the data was the result of contamination by modern DNA. Furthermore, the "singlerun" sequencing approach used by this group did not prevent multiple errors that appeared because of ancient DNA nucleotide modification and could only be excluded by multiple sequencing [26-28]. Errors were also detected in the published sequence of the mtDNA fragment from the Feldhofer cave Neanderthal [29]. Out of the 27 detected alterations, as compared to human mtDNA, 4 turned out to be artefacts [30]. The published nucleotide sequences of other species are also not free of errors (the Pleistocene cave bear [31], mammoth [32, 33], etc.).

Similar problems (exceedingly small amounts of DNA, or DNA damaged by thermal conditions or chemical agents) often come up during the genetic analysis of forensic samples. An analysis of these problems and approaches that allow to solve them are presented in this review.

\section{EXTRACTION OF DNA AND CONTAMINATION PROBLEM}

Paleontological and archeological materials and biological samples that are collected at excavation sites or stored in museums yield very small amounts of DNA that is usually highly fragmented. Moreover, this ancient DNA is modified in various ways that prevents amplification or lead to errors in nucleotide sequence reads. Because of the low efficiency of amplification of authentic DNA extracted from ancient and historic samples, contamination of the sample by even a single modern DNA molecule can produce errors. A number of specific measures must be taken in order to prevent contamination and to detect possible contamination. False positive results, caused by in-lab contamination, are one of the major problems in ancient DNA studies. That is why the key step in molecular-genetic analysis of ancient and historic samples is DNA extraction.

Extraction of DNA from ancient samples must be performed in accordance with sample age and quality. It particularly involves the choice of the detergent used for cell lysis. Sodium dodecyl sulfate (SDS) that is used in standard DNA extraction for the purpose of lipid destruction could be substituted by non-ionic detergents for soft lysis (Triton or Twin), or by detergent-free extraction, since lipids have been already destroyed in ancient samples, and the use of SDS lowers the DNA yield. Nevertheless, the use of detergents is recommended for more recent samples. Treating bone material with reagents that include EDTA causes sample decalcification and $\mathrm{pH}$ lowering, which can affect DNA binding on the columns used in downstream extraction procedures.

Studies of ancient DNA should be conducted in specially equipped facilities with all possible means for preventing contamination by modern DNA. It includes facilities with altered air pressure: high pressure in the rooms used for ancient DNA work and low pressure in rooms where modern DNA and amplified products are studied. These facilities must be regularly disinfected with chemicals and UV-radiation, to avoid any DNA (target, amplified or contaminant) and cell 


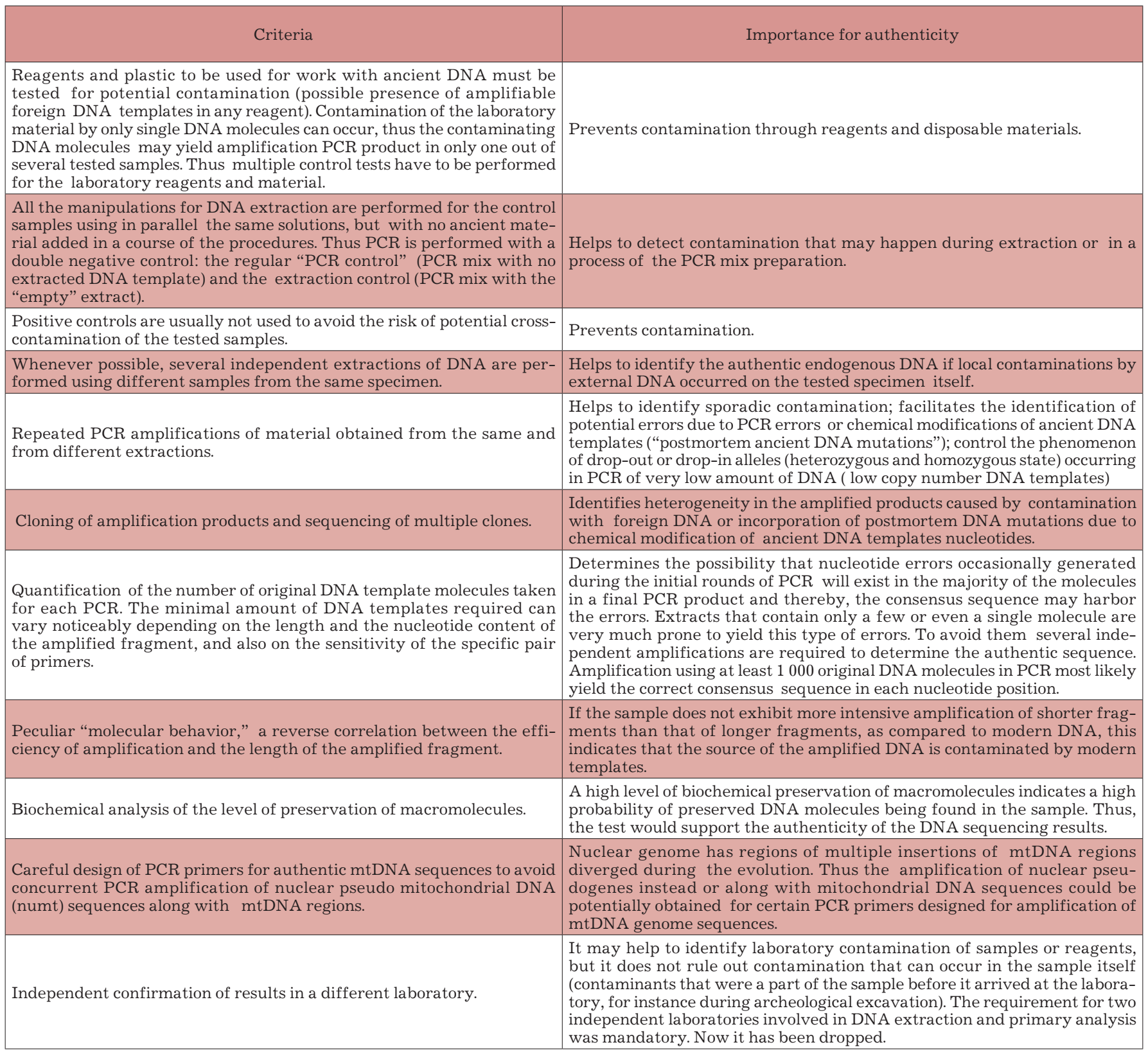

material (aerosols and dust with microorganisms and human and other organism's cells). Ancient DNA work must be conducted in protective clothing, gloves, and masks. A minimum requirement is that DNA extraction procedures performed on ancient DNA and involving single fragmented molecules must be performed in facilities physically separated from the ones for PCR-amplification and downstream amplified DNA procedures that work with millions of molecules. Facilities for ancient DNA handling must not house procedures with amplified fragments, as it is exceedingly difficult to prevent their spreading. DNA from modern organisms must be handled in a separate building, or at least a facility with a separate ventilation system. All these measures help to prevent contamination but do not affect the contamination of the sample itself that remains as it was before it ever got into the laboratory. In order to decrease contamination, the surface layer of the sample is usually removed.

Contamination is usually a very important issue in ancient human or microbal DNA studies, since both human and bacterial DNA are constantly present in laboratory. Thus, the sequences of contaminant DNA are harder to separate from the authentic DNA than when dealing with exotic or rare species. The guidelines for working with ancient DNA and the criteria of authenticity for the amplified ancient DNA fragments are described in the following reviews [4, 17, 34-36] and are listed in Table 1. 
Table 2. Various types of ancient DNA damage (from $[4,17]$ with modifications)

\begin{tabular}{|c|c|c|c|}
\hline Type of damage & Cause of damage & Effect on DNA & Possible solution \\
\hline $\begin{array}{c}\text { Nucleobases and deoxyribose } \\
\text { degradation }\end{array}$ & $\begin{array}{c}\text { Postmortem destruction } \\
\text { by intracellular nucleases, } \\
\text { degradation by microorganisms } \\
\text { and environmental chemical } \\
\text { processes }\end{array}$ & $\begin{array}{c}\text { Apurinization of DNA, strand } \\
\text { breaks, decrease of DNA frag- } \\
\text { ment size, decrease of the overall } \\
\text { amount of DNA }\end{array}$ & $\begin{array}{c}\text { Amplification of short (<100-200 bp) over- } \\
\text { lapping fragments }\end{array}$ \\
\hline Cross-links that block PCR & $\begin{array}{c}\text { Alkylation, Maillard reaction } \\
\text { (chemical reaction between a } \\
\text { sugar molecule and an amino } \\
\text { group of a nucleobase or an } \\
\text { amino acid) }\end{array}$ & $\begin{array}{c}\text { Cross-links between DNA strands } \\
\text { in a single molecule; cross-links } \\
\text { between DNA strands of different } \\
\text { molecules; or cross-links between } \\
\text { DNA and proteins }\end{array}$ & Treating the sample with reagents that \\
destroy cross-links
\end{tabular}

\section{IDENTIFYING CONTAMINATION}

Possible contamination can be identified with a high degree of accuracy during ancient DNA studies if it is a priori supposed that the sample could be contaminated, so that the results are viewed with this possibility in mind. In order to identify laboratory contamination, researchers use "empty" extracts that have been processed along with the target sample but without adding tissue sample or DNA. Since contamination templates can be present in very low concentrations and not manifest themselves in each reaction, multiple control reactions are made, usually in proportion 1:5, but with no fewer than 1:1 to the extracted sample. Such "empty" extracts are used in all further analytic procedures in addition to the regular negative controls.

Independent confirmation of results in different laboratories is considered to be one of the strong indicators of authenticity. But even this is not an absolute guarantee [36].

Special attention must be paid to bioinformatic analysis of the obtained nucleotide sequences. Since analysis of ancient samples usually involves mtDNA analysis, it is important to compare the sequence not only with the mtDNA of species closely related to the sample source or with human mtDNA (the most likely source of contamination), but also with the nuclear homologues of mtDNA genes (nuclear mtDNAs, numts), whose similarity to mtDNA is $\sim 98 \%$ and more in case of human mtDNA (such as the NT_004350.18 sequence located on Chromosome 1).

\section{CHEMICAL MODIFICATIONS OF ANCIENT DNA AND POSTMORTEM MUTATIONS}

Postmortem DNA alterations, and mutations during in vitro DNA amplification, are among the central methodological problems in ancient DNA and complex forensic DNA analysis. As opposed to metabolically active tissues that have an active DNA reparation system postmortem cells accumulate chemical (hydrolytic or oxidative) DNA modifications and strand damage. Studies show that postmortem DNA damage includes strand breaks, loss of bases and cross-linking between strands that inhibits PCR. Postmortem alterations that modify bases but do not inhibit amplification are espe- cially important, since they can cause the appearance in the amplification products nucleotide of changes that were not present in the authentic sequence (type I substitutions $\mathrm{A} \rightarrow$ $\mathrm{G} / \mathrm{T} \rightarrow \mathrm{C}$ and type $\mathbf{I I}$ substitutions $\mathrm{C} \rightarrow \mathrm{T} / \mathrm{G} \rightarrow \mathrm{A}$ ) (Table 2). The manner how the degraded DNA templates are damaged depends on the samples age, their geographic origin, and the taphonomic conditions (preservation conditions) of the environment where the samples were stored. Postmortem alterations can appear in mutational hot-spots, thus simulating evolutionary mechanisms [37]. The manner and dynamics of accumulation of postmortem DNA alterations are under continuous research $[38,39]$. DNA damage limits the size of the DNA fragments found in ancient samples to about $100-500$

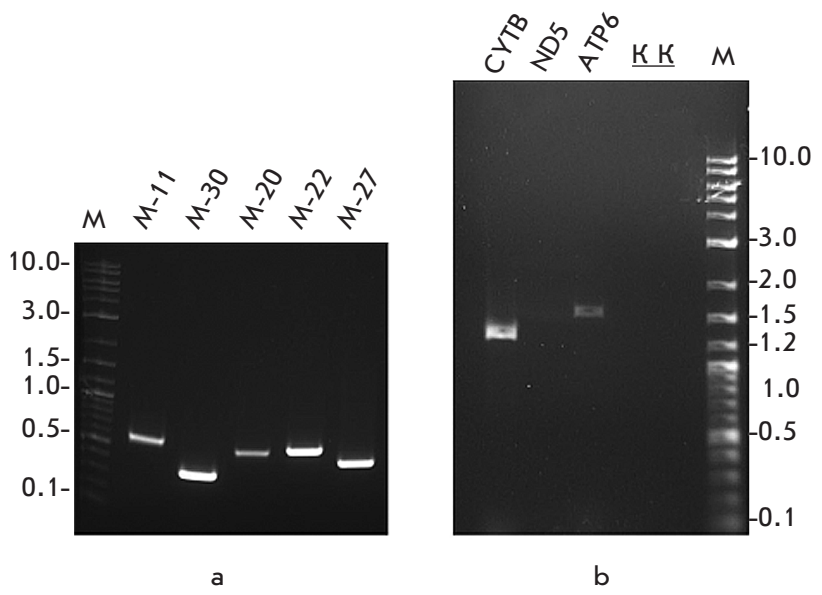

Fig. 2. A typical result of PCR amplification of mammoth mitochondrial genome fragments:

a - PCR products of relatively short amplification fragments (300-600 bp); $b$ - Successful amplification of long PCR fragments harboring entire mitochondrial gene sequences (1317 bp for the CytB gene and 1613 bp for the ATP6 gene) and no amplification products are obtained for larger size PCR fragments (3054 bp for the ND5 gene). M -marker fragment sizes are indicated in $\mathrm{kb}, \mathrm{K}$ - negative controls [13] 


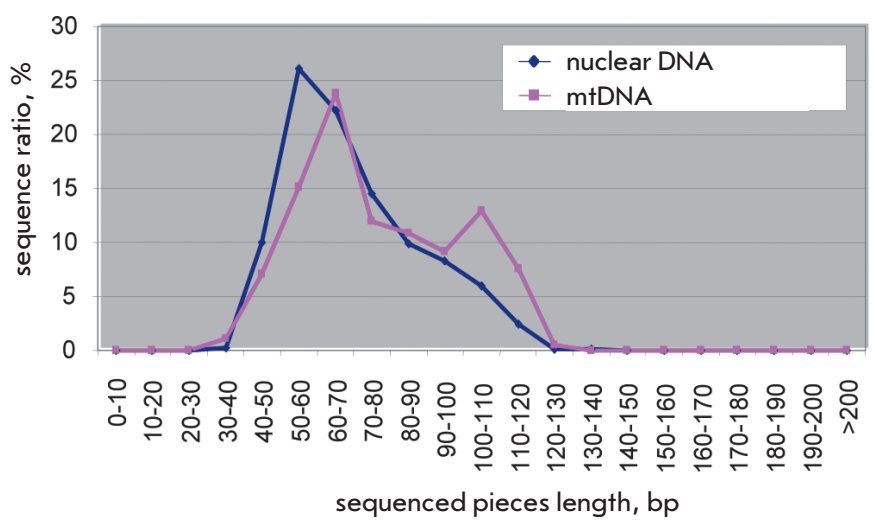

Fig. 3. The size distribution of genomic DNA fragments extracted from the ancient remains sequenced on the 454 platform. Unpublished data obtained in collaboration of E.I. Rogaev et al. with M. Blow and E. Rubin

bp. That is why the primers for ancient DNA PCR are usually chosen for no more than 200-300 bp fragments, although fragments of greater length have been obtained in some cases (Fig. 2).

Most of the published ancient DNA studies have been conducted on mtDNA that is found in hundreds and thousands of copies in cell and can be amplified more successfully than nuclear DNA. There are much fewer studies on nuclear DNA. Amplification, cloning, and sequencing of nuclear DNA from a mammoth $M$. primigenius sample obtained from Chukotka permafrost was performed in order to assess the quality of nuclear DNA preservation (E.I. Rogaev, E. Rubin, unpublished data). Most of the mammoth genome was fragmented into pieces of about 50-100 bp (Fig. 3). It indicates a relatively high quality of nuclear DNA preservation.

Postmortem modifications are randomly located in the preserved DNA fragments. For example, single nucleotide substitutions ( 6 in $1000 \mathrm{bp}$ ) were found in one study [13] during the cloning and sequencing of PCR-amplified mammoth DNA. This observation was taken into account for correct reconstruction of the complete mitochondrial genome of Chukotka mammoth M. primigenius (Fig. 4). The complete genome was obtained as a consensus of multiple overlapping fragments [13]. In order to additionally control the number of postmortem mutations, the overall number of substitutions in all mammoth mtDNA genes was calculated in comparison with elephant E. maximus mtDNA. The ratio between nonsynonymous (that cause aminoacid substitutions) and synonymous substitutions was calculated for the same purpose. It was shown that the number of substitutions in the mtDNA genes of the Chukotka mammoth [13] was lower than in the genes of a mammoth sequence obtained from remains found in Yakutia that was published at the same time by German researchers [40]. A comparative analysis showed that this difference was due to the unusually high number of substitutions in a 200-300 nucleotide region of the Yakut mammoth DNA in the locus of ND1 and ND2 genes, and that the number of nonsynonymous substitutions was greater than the number of synonymous ones (2:1 for the ND1 gene and 7:2 for ND2). The ND2 gene of the Chukotka mammoth had only one synonymous substitution, and ND1 did not differ in any way from the elephant gene [13]. All undetected postmortem mutations affect the result of phylogenetic reconstruction.

\section{NOVEL DNA-SEQUENCING TECHNOLOGIES}

Ancient DNA analysis involves sequencing of a large number of short fragments that have multiple overlapping of the same genomic regions. Low sequencing speed and high cost limit the usage of such research. Novel technologies of massively parallel sequencing of a large amount of DNA samples have appeared in the last 3-4 years, and the cost has dropped by two orders of magnitude. This novel technologies have given researchers sequencing possibilities that were previously available only to large genomic centers. Among the available novel technologies several were used in ancient DNA studies, such as clonal amplification followed by parallel sequencing of dense micropanels of cloned DNA fragments by repeated enzymatic reaction cycles, with automatic registration of the signal from each cycle and every fragment.

The ordered spatial localization of the PCR amplicons on a chip or immobilization on microne-sized beads that are then placed into ordered cells allows to minimize the reaction mix volumes, thus decreasing the cost of the whole process.

Realization of these strategies involves several steps, and for each of them a specific technical approach has been developed. For example, preparation of DNA fragment libraries using PCR does not keep the ratio of amplification products identical to the ratio of original templates. Some DNA fragments are amplified more efficiently than others that could be lost. The problem can be solved by using emulsion PCR.

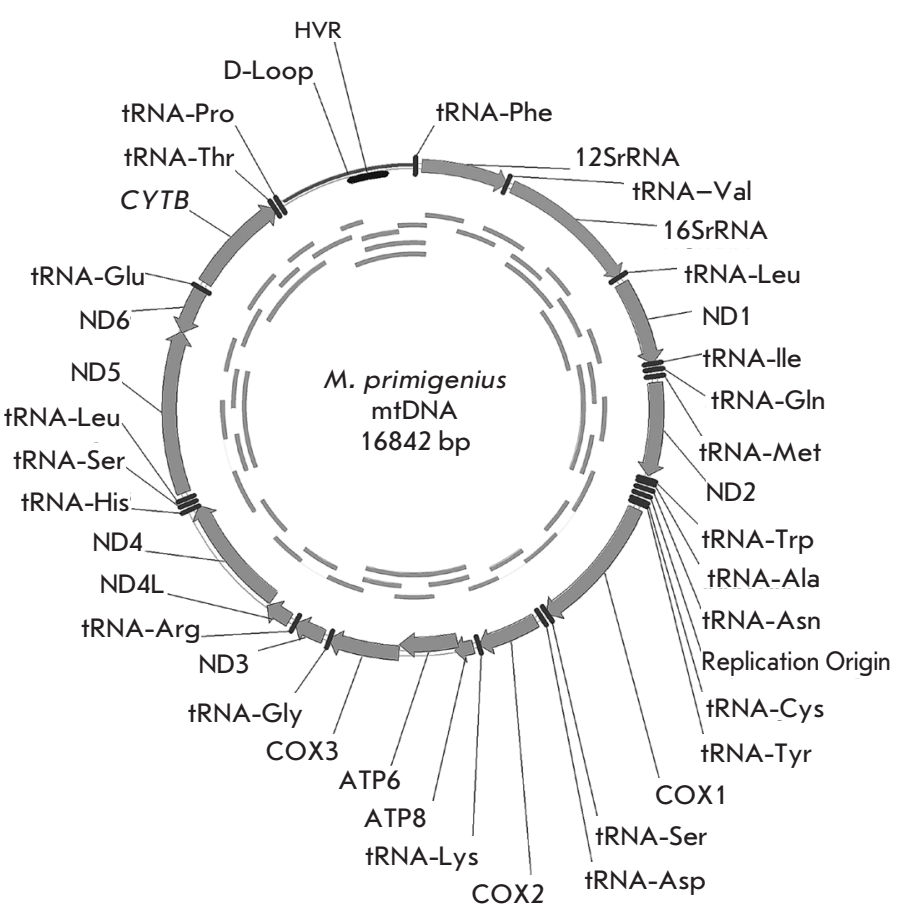

Fig. 4. Mitochondrial genome of the woolly mammoth M. primigenius. Determination of the nucleotide sequence of the complete mitochondrial genome was performed in two laboratories. The overlapping PCR-amplification products used for sequencing are shown in the inner circle [13] 
The DNA solution is transferred into the mineral oil mix. The ratio is calculated so that each molecule of DNA is encapsulated in a separate lipid droplet that acts as a microreactor for the amplification process. This approach minimizes the loss of certain original templates. There are various technical solutions for fragment library preparation and for the other steps in the process, such as enzymatic reactions, visualization and computerized signal registration, data storage and analysis [41].

Novel sequencing technologies have certain limitations. Massively parallel pyrosequencing, accomplished by using 454 Life Science system (Genome Sequence 20TM DNA sequencing System: GS20, Roche/454 Life Science), provides a 100-fold increase in the sequencing speed, compared to the standard capillary electrophoresis method. Up to 25 million nucleotides are analyzed in a single run. Only a short sequence can be read (usually less than $250-400 \mathrm{bp}$ ). It is not much of a limitation for ancient DNA studies, since most of the DNA fragments are precisely of this size.

The Illumina technology, named Solexa (after the name of the company that developed this approach), and SOLiD (ABI corporation) allow the analysis of up to 1 billion nucleotides in a single run but read sequences of only 30-40 nucleotides (last year this number was just 25 nucleotides). The availability of full human genomes and the genomes of commonly used model organisms as reference sequences allow to map the short fragments into a single contig.

Another limitation of these novel platforms is the 10 -fold decrease in the accuracy of sequencing, compared to the Sanger method. Nevertheless, these technologies are very promising, and they can be expected to improve in efficiency and quality in the nearest future.

\section{ANALYSIS OF DEGRADED DNA IN FORENSIC EXPERTISE OF HISTORIC SAMPLES}

The technological approaches applied for ancient DNA study can also be used for forensic genetic analysis in difficult cases where only microscopic amounts of material are available or the DNA has been severely damaged. Some of these approaches were used in the genetic expertise of the putative remains of the family of the last Russian Emperor Nicholas II Romanov. In the early 1990s, a first grave with human remains was found near Yekaterinburg. During the investigation, it was suggested that the remains belong to the family of the Russian Emperor Nicholas II Romanov, his wife, the Empress Alexandra Fedorovna, their 3 daughters, the court physician, and three servants. They are all thought to have been murdered in 1918 [42-44]. However, the remains of two children of the Romanov family were not identified, and their fate remained unknown. Among other hypotheses, there has been a legend that Alexey and Anastasia, the youngest children of the Romanov family, had survived those turbulent times. In July 2007, a second grave was found not far from the first one. It contained burned bone fragments from two skeletons. Forty-four bone fragments were found in the second grave, all severely damaged by fire and presumably sulfuric acid. Preliminary anthropological analysis of the half-burned bone fragments from the second grave suggested that the bones belonged to a boy 10-14 years of age and young woman of about 18-23. The least damaged frag- ments of the femoral bones from both the male and female skeletons were selected for genetic analysis, and they were labeled Samples 146 and 147, respectively. Samples from the first grave were also collected for a more detailed study, and reference samples were taken from living relatives of Nicholas Romanov and Alexandra Fedorovna. Furthermore, swabs of blood stains from a shirt that had belonged to Nicholas II and is stored in the Hermitage museum were also used for analysis. The study included the following steps: preparation of the samples for DNA extraction; DNA extraction; quantification of the extracted total DNA and human-specific DNA; amplification and sequencing of the mitochondrial hypervariable regions, and later sequencing and reconstruction of the complete mtDNA (cmtDNA) sequence; determination of the STR-profiles of the Y-chromosome; determination of the autosomal STR-profiles; additional sex identification with the use of a special marker designed for degraded DNA analysis [45, 46]; and extraction and analysis of modern DNA from Romanov family relatives and their comparison to historic samples. The steps and methods of DNA identification are described in Table 3 [45].

\section{MITOCHONDRIAL GENOME ANALYSIS}

Complete nucleotide sequences of the mitochondrial genome have been determined for the putative remains of Nicholas II and Alexandra Fedorovna from the first grave; and the putative remains of Alexey and his sister, from the second grave. The mitotypes of the putative remains of Nicholas II and Alexandra Fedorovna are from the common European mtDNA haplogroups $\mathrm{T} 2$ and $\mathrm{H} 1$.

Complete cmtDNA sequences were also determined for the relatives of Queen Victoria (1819-1901) for 2 maternal lineages, the descendants of princess Victoria, sister of Alexandra Fedorovna, and their aunt Beatrice (Fig. 5). Their cmtDNA were absolutely identical with those extracted from the putative remains of Alexandra Fedorovna and the 2 children from the second grave. Searches performed in the available cmtDNA databases (Table 4) showed that not one of the available tens of thousands of sequences identifies with this cmtDNA, which was named "Queen Victoria mitotype." Thus, the first and second burial sites really do contain the remains

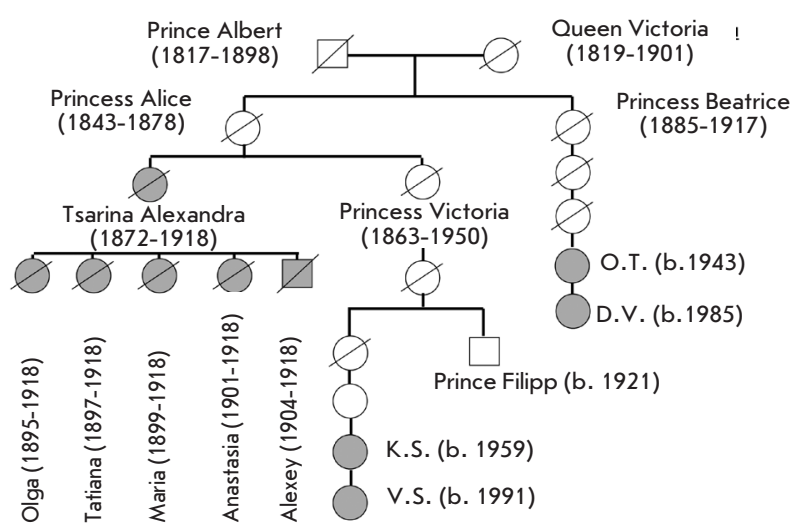

Fig. 5. Maternal lineages of Empress Alexandra Fedorovna. The family members whose mitochondrial DNA was determined are indicated in grey 


\begin{tabular}{|c|c|c|}
\hline Stage of analysis & Special procedures & Reagents and methods \\
\hline $\begin{array}{l}\text { Preparation of histori- } \\
\text { cal samples }\end{array}$ & $\begin{array}{c}\text { Independent analysis in specialized laboratories in VIGG } \\
\text { (Moscow) and University of Massachusetts Medical } \\
\text { School (Worcester, USA). }\end{array}$ & $\begin{array}{l}\text { Physical and chemical cleaning of small bone fragments, } \\
\text { crushing or drilling to obtain bone powder. }\end{array}$ \\
\hline $\begin{array}{l}\text { Extraction of DNA } \\
\text { from archival blood- } \\
\text { stains }\end{array}$ & $\begin{array}{c}\text { The biological material was obtained from } 4 \text { different } \\
\text { blood stains. At least } 3 \text { swabs were taken from each spot. } \\
\text { In order to minimize contamination, DNA was extracted } \\
\text { only from the } 2^{\text {nd }} \text { and } 3^{\text {rd }} \text { swabs for each spot. }\end{array}$ & $\begin{array}{l}\text { DNA was extracted with the QIAamp DNA Mini Kit (Qiagen) } \\
\text { using the manufacturer's protocol ("DNA Purification from } \\
\text { Dried Blood Spots") with our own modifications. }\end{array}$ \\
\hline $\begin{array}{l}\text { Quantification DNA } \\
\text { analysis }\end{array}$ & & $\begin{array}{l}\text { The total extracted DNA was quantified by the Quant-iT } \\
\text { PicoGreen }{ }^{\mathrm{TM}} \text { Assay kit (Invitrogen), human specific DNA was } \\
\text { quantified by the Plexor }{ }^{\circledR} \text { HY assay kit (Promega) and the } \\
7500 \text { Real-Time PCR System (Applied Biosystems). }\end{array}$ \\
\hline $\begin{array}{l}\text { Sequencing of HVR1 } \\
\text { and HVR2 of mtDNA } \\
\text { from historical samples }\end{array}$ & $\begin{array}{l}\text { Potential contamination by foreign DNA was monitored } \\
\text { by using negative controls (amplification of "empty" } \\
\text { extracts and PCR without addition of the template). }\end{array}$ & $\begin{array}{l}\text { mtDNA fragments were amplified as short overlapping } \\
\text { fragments. The PCR products were then extracted from the } \\
\text { agarose gel using a QIAquick Gel Extraction kit or a MinElute } \\
\text { Gel Extraction kit. For additional studies, the PCR products } \\
\text { from some specimens were cloned. }\end{array}$ \\
\hline $\begin{array}{l}\text { Analysis of the mtDNA } \\
\text { extracted from the } \\
\text { blood stains on shirt } \\
\text { that belonged to } \\
\text { Nicholas II. }\end{array}$ & $\begin{array}{c}\text { Extraction of DNA was performed from different swabs } \\
\text { from at least } 3 \text { shirt blood stains. Up to } 5 \text { or } 7 \text { PCR repli- } \\
\text { cations were conducted for some of the mtDNA SNPs to } \\
\text { identify the potential heterogeneity and contamination } \\
\text { by other individuals and selection of the extracts pre- } \\
\text { senting mitotype likely from one individual only. }\end{array}$ & $\begin{array}{l}\text { Since the quality of preservation in the blood stains was } \\
\text { unknown, initially a set of primers was developed for the } \\
\text { amplification of short ( } 64-109 \text { bp) DNA fragments that would } \\
\text { include very rare SNPs identified in the previous analysis of } \\
\text { Skeleton №4 (the putative skeleton of Nicholas II). }\end{array}$ \\
\hline $\begin{array}{l}\text { Extraction and analysis } \\
\text { of DNA from modern } \\
\text { samples. }\end{array}$ & $\begin{array}{c}\text { For modern DNA analysis all the procedures were } \\
\text { performed in separate buildings, physically separated } \\
\text { from the ancient DNA laboratories. Informed consent was } \\
\text { obtained from all living relatives participating in the study. }\end{array}$ & $\begin{array}{l}\text { DNA obtained from buccal swabs or drops of blood was } \\
\text { extracted using standard protocols. PCR was performed using } \\
\text { a set of primers for amplifying longer fragments. }\end{array}$ \\
\hline $\begin{array}{l}\text { Analysis of nuclear } \\
\text { STR markers. }\end{array}$ & $\begin{array}{l}\text { mtDNA or nuclear DNA extracts that consisted of a mix } \\
\text { of individual profiles were discarded from further analy- } \\
\text { sis. Each sample from various extracts was amplified in } \\
\text { multiple replications. Homozygous loci were considered } \\
\text { authentic if multiple independent amplifications con- } \\
\text { firmed a certain allele for the autosome STR-marker. }\end{array}$ & $\begin{array}{l}\text { The following kits were used in order to obtain autosomal } \\
\text { STR profiles from bone samples of the first and second burial } \\
\text { sites: AmpFISTR@ MiniFiler }{ }^{\text {Ts }} \text { PCR Amplification Kit (Applied } \\
\text { Biosystems) and PowerPlex S5 System (Promega), specifically } \\
\text { designed for analyzing degraded DNA. }\end{array}$ \\
\hline $\begin{array}{l}\text { STR-profiles of the Y } \\
\text { chromosome. }\end{array}$ & & $\begin{array}{l}\text { The AmpFISTR® Yfiler }{ }^{\mathrm{TM}} \text { (Applied Biosystems) kit was used, } \\
\text { according to the manufacturer's protocol with minor modifica- } \\
\text { tions for analysis of degraded DNA. }\end{array}$ \\
\hline Electrophoresis analysis & $\begin{array}{c}\text { In order to increase the signal intensity and lower "noise" } \\
\text { in the STR-profiles, the products of multiplex amplifica- } \\
\text { tion were sometimes purified with Qiagen MiniElute } \\
\text { columns. }\end{array}$ & $\begin{array}{l}\text { Electrophoretic analysis was performed using a 96-capillary } \\
\text { sequencer 3730xl DNA Analyzer (Applied Biosystems). The } \\
\text { results were analyzed with GeneMapper }{ }^{\circledR} \text { ID software v3.2 } \\
\text { (Applied Biosystems). }\end{array}$ \\
\hline
\end{tabular}

of Queen Victoria's granddaughter, great granddaughter, and great grandson.

Determination of the cmtDNA from the putative remains of Nicholas II confirmed the earlier described heteroplasmy (the coexistence of several mtDNA types) at the $16169 \mathrm{C} / \mathrm{T}$ site. Moreover, nucleotide substitutions were found in the coding region of the mtDNA, including the extremely rare
$2850 \mathrm{C}$ variant in the $16 \mathrm{~S}$ rRNA gene (population frequency approximately 0.004 ). Nucleotide substitutions in the mtDNA from the putative remains of Nicholas II and from the blood stains on the shirt were completely identical [45]. The ratio between the heteroplasmic mtDNA variants was similar both in the remains and in the blood. Nicholas II's brother, George, whose remains were studied previously, also had heteroplas- 


\begin{tabular}{|c|c|c|}
\hline Query sequence & $\begin{array}{l}\text { Number of } \\
\text { samples in the } \\
\text { database }\end{array}$ & Name of the database \\
\hline $\begin{array}{l}\text { Complete } \\
\text { mitochondrial } \\
\text { genome }\end{array}$ & $\begin{array}{l}71,664 \\
2,704 \\
14,486\end{array}$ & $\begin{array}{l}\text { Mitosearch (www.mitosearch.org) contains sequences of the hypervariable region; } \\
\text { mtDB, Human Mitochondrial Genome Database (www.genpat.uu.se/mtDB); } \\
\text { EUROS, our own database, compiled from our own and other authors' published data for the USSR and } \\
\text { Russian populations and for certain European populations (German, English, etc.). }\end{array}$ \\
\hline $\begin{array}{l}\text { STR-haplotype of } \\
\text { the Y-chromosome }\end{array}$ & $\begin{array}{l}4,163 \\
1,261\end{array}$ & $\begin{array}{l}\text { U.S. Consolidated Y-STR Database has genotypes for 15-17 Y-STR loci (http://www.usystrdatabase.org/); } \\
\text { Data for Russians from the Y Chromosome Haplotype Reference Database (YHRD, www.yhrd.org/index.html). }\end{array}$ \\
\hline $\begin{array}{l}\text { Mutation in the } \\
\text { IVS3-3 position of } \\
\text { the F9 gene }\end{array}$ & & $\begin{array}{l}\text { Population SNP database (NCBI, HapMap Project); } \\
\text { 928 X-chromosomes of healthy individuals of European descent whose genotypes were assessed for this } \\
\text { SNP using PCR-RFLP (Restriction Fragment Length Polymorphism) especially for this study; } \\
\text { Hemobase: Hemophilia B mutation registry, Haemophilia B mutation database. }\end{array}$ \\
\hline
\end{tabular}

my at the same site [43]. The descendants of Kseniya, sister of Nicholas II, had the homoplasmic $16169 \mathrm{~T}$ variant, and the previously performed mtDNA study of Nicholas II's sister's son found the homoplasmic $16169 \mathrm{C}$ variant [44]. Not one of the reconstructed complete mtDNA sequences ("Dagmar" type) was identified in available databases (Table 4), which confirms the assumption that the studied remains belong to Nicholas II. The data suggest that the brothers Nicholas II and George Romanov inherited heteroplasmy from their mother Maria Fedorovna (Princess Dagmar), and that her descendants had this heteroplasmy segregated into two distinct mtDNA variants in two generations. The nucleotide substitution at position 16169, on which the heteroplasmy of the "Dagmar type" is based, is located in the noncoding (hypervariable) region of the mtDNA characterized by increased polymorphism compared to the coding regions. The population frequency of heteroplasmy for point substitutions in hypervariable regions averages $6 \%$ [47]. It is assumed that rapid segregation of heteroplasmic mtDNA variants in descendants is caused by mechanisms of biological "bottle-neck" (a massive decrease in the number of mtDNA copies) during oocyte maturation in the postnatal folliculogenesis in mammals [48].

\section{NUCLEAR STR-MARKER ANALYSIS}

To study the paternal lineage DNA profiles of the putative remains of Emperor Nicholas II and Prince Alexey, the STRhaplotypes of the Y-chromosome were determined. Specialized procedures were developed in order to increase the PCR sensitivity, since the amount of the available DNA was limited, and the molecules were highly fragmented (some of the methods are described in Table 3) [45]. The STR-profiles were determined from multiple independent PCR amplifications using no less than three different DNA extracts. Only the alleles that were identified in no less than 2 amplifications were considered authentic. A full Y-STR profile for the bone specimen of Skeleton №4 and for the museum samples of Nicholas II's blood was obtained using these criteria. Low-copy highly fragmented DNA often loses single STR alleles. Marker DYS385 shows two loci on the Y-chromosome. The high mo- lecular weight allele (DYS385/ 14) was identified only once in the repeated experiments with the DNA extracted from Sample \#146, thus this allele for Sample \#146 is indicated as not determined (ND). DNA isolated from the archival Nicholas II bloodstain and DNA obtained from Romanov paternal lineage family members were used as reference samples (Fig. $6)$. Y-chromosome STR-profiles of the studied samples and the reference sequences were completely identical (Fig. 7 and Table 5). This 17-locus Y-STR haplotype is unique. It is not found in large population databases for multi-locus Y-STR (Table 4) and was first encountered in the described study [45].

Further gender and autosomal chromosome genotyping with STR multiplex systems developed especially for degraded DNA demonstrated that the male (Sample № 146) and the female (Sample № 147) from the second grave have

Table 5. STR-haplotype analysis of the Y-chromosome [45]

\begin{tabular}{|c|c|c|c|c|c|}
\hline Markers & № 4 & № 146 & $\begin{array}{c}\text { Members of } \\
\text { the Romanov } \\
\text { family }\end{array}$ & $\begin{array}{c}\text { Archive } \\
\text { blood stain } \\
\text { from a shirt }\end{array}$ & $\begin{array}{c}\text { Control } \\
\text { DNA } \\
\text { ABI, 007 }\end{array}$ \\
\hline DYS456 & 16 & 16 & 16 & 16 & 15 \\
\hline DYS389I & 13 & 13 & 13 & 13 & 13 \\
\hline DYS390 & 24 & 24 & 24 & 24 & 24 \\
\hline DYS389II & 29 & 29 & 29 & 29 & 29 \\
\hline DYS458 & 17 & 17 & 17 & 17 & 17 \\
\hline DYS19 & 14 & 14 & 14 & 14 & 15 \\
\hline DYS385 & 11,14 & 11, ND & 11,14 & 11,14 & 11,14 \\
\hline DYS393 & 13 & 13 & 13 & 13 & 13 \\
\hline DYS391 & 10 & 10 & 10 & 10 & 11 \\
\hline DYS439 & 11 & 11 & 11 & 11 & 12 \\
\hline DYS635 & 24 & 24 & 24 & 24 & 24 \\
\hline DYS392 & 13 & 13 & 13 & 13 & 13 \\
\hline Y-GATA-H4 & 12 & 12 & 12 & 12 & 13 \\
\hline DYS437 & 15 & 15 & 15 & 15 & 15 \\
\hline DYS438 & 12 & 12 & 12 & 12 & 12 \\
\hline DYS448 & 19 & 19 & 19 & 19 & 19 \\
\hline
\end{tabular}


Fig. 6. Heteroplasmy at the $16169 \mathrm{C} / \mathrm{T}$ locus in the mitochondrial (maternal) lineages of Emperor Nicholas II

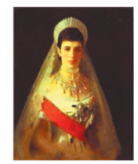

Maria Fedorovna (Princess Dagmar)

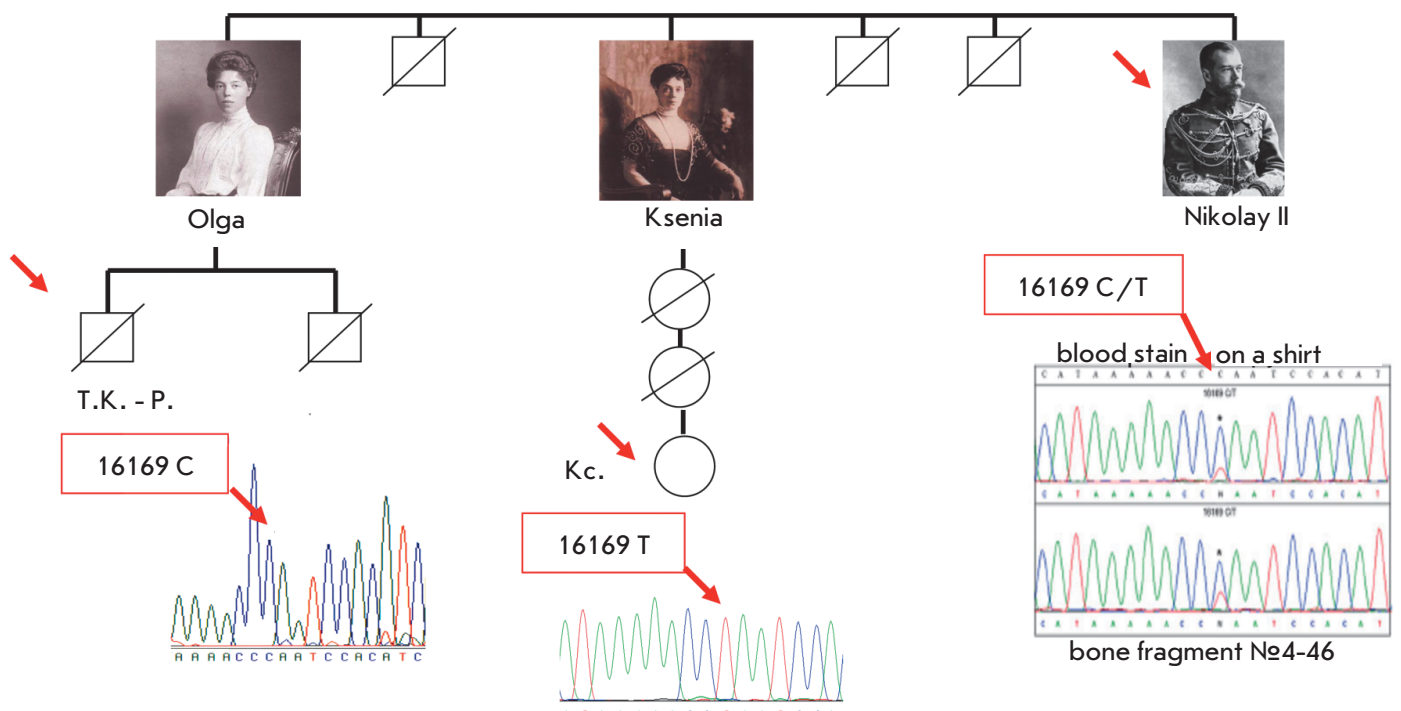

autosomal STR profiles nonidentical to any STR profiles determined for Romanov family remains from the first grave but consistent with a biological kinship connection (Fig. 8). These data clearly demonstrate that these newly found remains may belong to Prince Alexey and one of the daughters of the imperial family. The available nuclear DNA analysis data, supported by the anthropological data, prove that the remains from the second grave belong to a young woman (№ 147) and a boy (№ 146), and that samples from the second grave are not from Skeleton № 7 (putative mother, Empress Alexandra Fedorovna) or Skeleton № 4 (putative father, Emperor Nicholas II); however, they are related through the paternal and maternal lineages.

The statistical evaluation (likelihood ratio) based on three identification approaches for determining whether the bones belong to Nicholas II, and not to any other random individual, is on the order of a septillions $\left(>10^{26}\right)$ [45]. Taken together our data establish beyond reasonable doubt that the studied remains belong to the last Russian Emperor Nicholas II Romanov, his wife the Empress Alexandra Fedorovna, their 4 daughters (the Grand Duchesses Olga, Tatiana, Maria, and Anastasia), and their son (Prince Alexey).

\section{HEMOPHILIA: SEARCH FOR MUTATIONS IN THE GENES FOR BLOOD CLOTTING FACTORS}

There is historical evidence that Prince Alexey suffered from severe bleeding that is characteristic of hemophilia. It is now known that hemophilia is caused by insufficient activity of blood clotting factors. Factor VIII deficit caused by mutations in the $F 8$ gene is the cause of the most common hemophilia $\mathrm{A}$ (about one in 5000 boys is born with this disease), and Factor IX deficit causes hemophilia B (F9 gene), which occurs 5 times less often.
A few hundred mutations that cause hemophilia have been described to this day. Both of the blood clotting factor genes are localized on the $\mathrm{X}$-chromosome; that is why males carrying the mutant gene exhibit the disease. Females carrying a single copy of the mutant gene and a copy of the normal one are healthy in most cases, although some of them (10\%) can exhibit decreased efficiency of blood clotting. Females can be assessed for hemophilia mutations when their sons have hemophilia.

This inherited disease was common in the royal families of Europe, the sons, grandsons, and great grandsons of Queen Victoria (Fig. 9, c). The Queen herself did not suffer from this illness, but it seems that she carried the mutant gene. There is no evidence of hemophilia in any of her present living relatives.

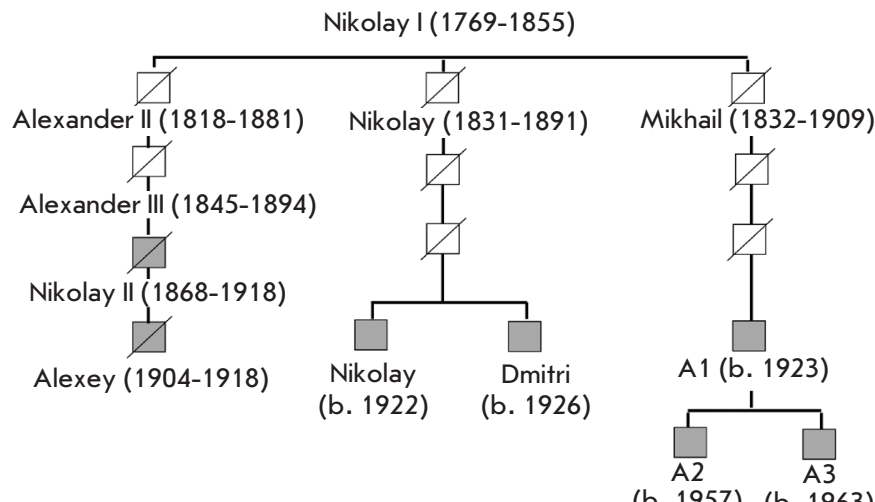

(b. 1957) (b. 1963)

Fig. 7. The paternal lineages of the Romanov family. The family members whose DNA was studied are indicated in grey 


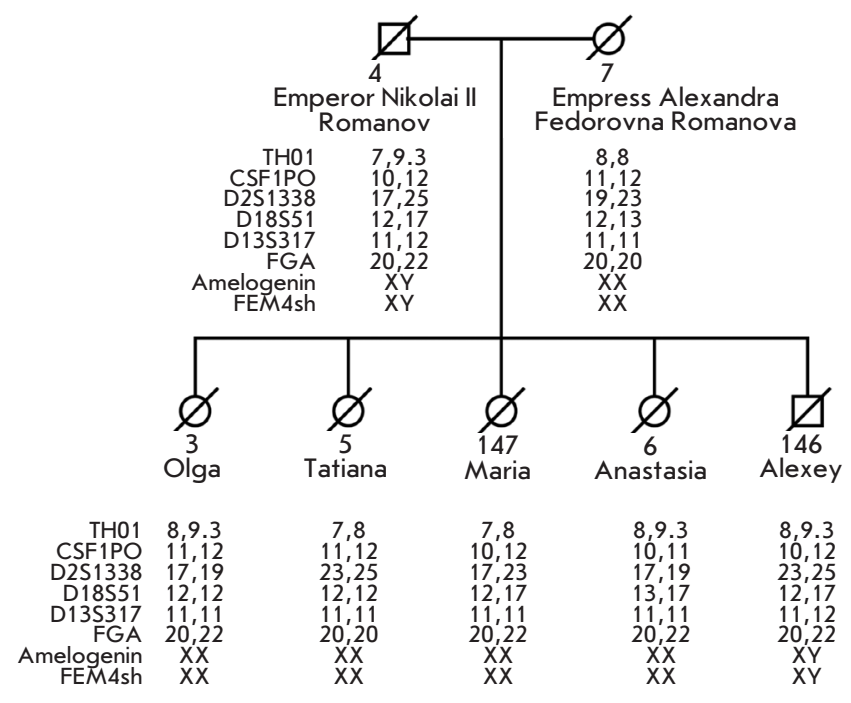

Fig. 8. Analysis of the sex chromosome and autosomal STR-markers in DNA extracted from bone specimens [45]

In order to determine whether Alexandra Fedorovna or Prince Alexey carried any mutations in genes, all the exons and the intron-exon boundaries of $F 8$ or $F 9$ genes were amplified using multiplex amplification reaction and then sequenced by massively parallel sequencing. Miniscule amounts of DNA and its high level of degradation required special procedures for the identification of the nucleotide sequences that included the 26 exons of the $F 8$ gene and the 8 exons of the F9 gene (the strategy and methods used in this study are described in Table 6).

The first step was to analyze DNA extracts from Alexandra that showed no contamination based on the results of mtDNA and autosomal STR-marker analysis. Amplification of the $F 8$ gene and the 8 exons of the $F 9$ gene was performed in parallel with the amplification of mtDNA that was used as a control and for accurate identification of the sample. Nonsynonymous substitutions or insertion-deletion mutations were not found in either the $F 8$ or $F 9$ gene. However, we detected a single nucleotide substitution of $A=>G$ at an intron-exon boundary and, 3 nucleotides before the start of the $4^{\text {th }}$ exon of the F9 gene (referred to as IVS3-3A $>$ G according to standard nomenclature). As expected for a heterozygote carrier, Alexandra Fedorovna carried both mutant and wildtype sequences. Alexey bear only the mutant allele, meaning that he was homozygous for this mutation, while one of his sisters (presumably Anastasia) was a heterozygous carrier of the mutation. The other sisters did not carry the mutant alleles; they were homozygous carriers of the wild-type allele (Fig. 9) [49].

Bioinformatic analysis showed that the IVS3-3A $>$ G mutation activates the cryptic splicing acceptor site, which leads to frame-shift during the translation of the F9 gene mRNA and the appearance of a premature stop-codon (Fig. 9, a).

The effect of this mutation on RNA splicing was studied by expressing the mutant fragment of the F9 gene in a cell culture using a specialized recombinant Exontrap vector (MoBiTec). We found that $99.98 \%$ of transcripts were generated by splicing at the mutant site. Less than $1 \%$ of the activity of Factors VIII or IX leads to severe manifestations of hemophilia [50]. Population database searches and genotyping

Table 6. Methods used in screening for mutations of the F8 and F9 genes [49]

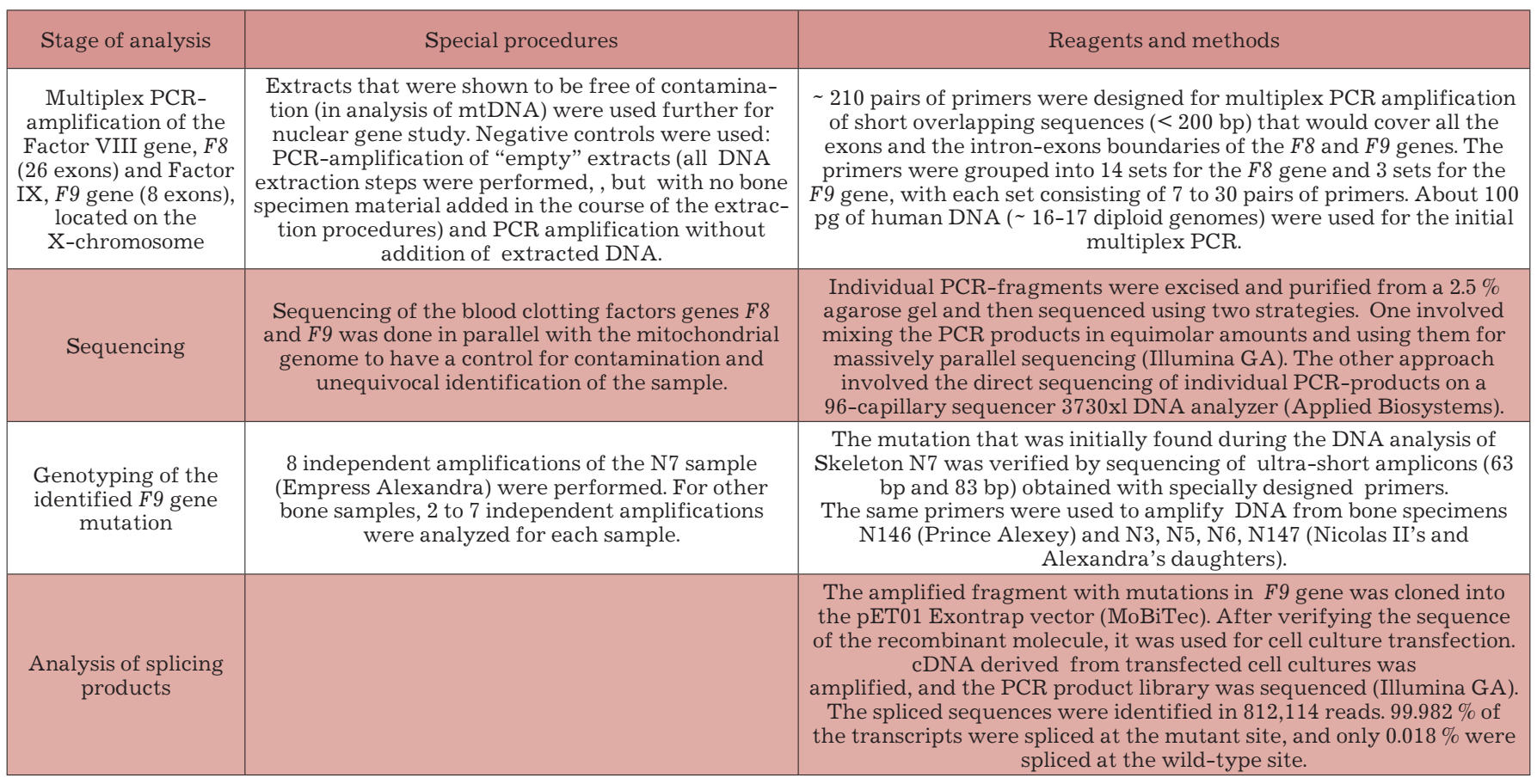




\section{REVIEWS}

Fig. 9. Hemophilia in the royal families of Europe: a - the point mutation in the F9 gene of the bloodclotting factor, that creates an alternative splicing site [49]; $\mathrm{b}$ - the pedigree demonstrating the inheritance of hemophilia from Queen Victoria to her descendants; c - sequencing chromatograms of the $F 9$ gene sequence obtained during the analysis of DNA extracted from bone remains a

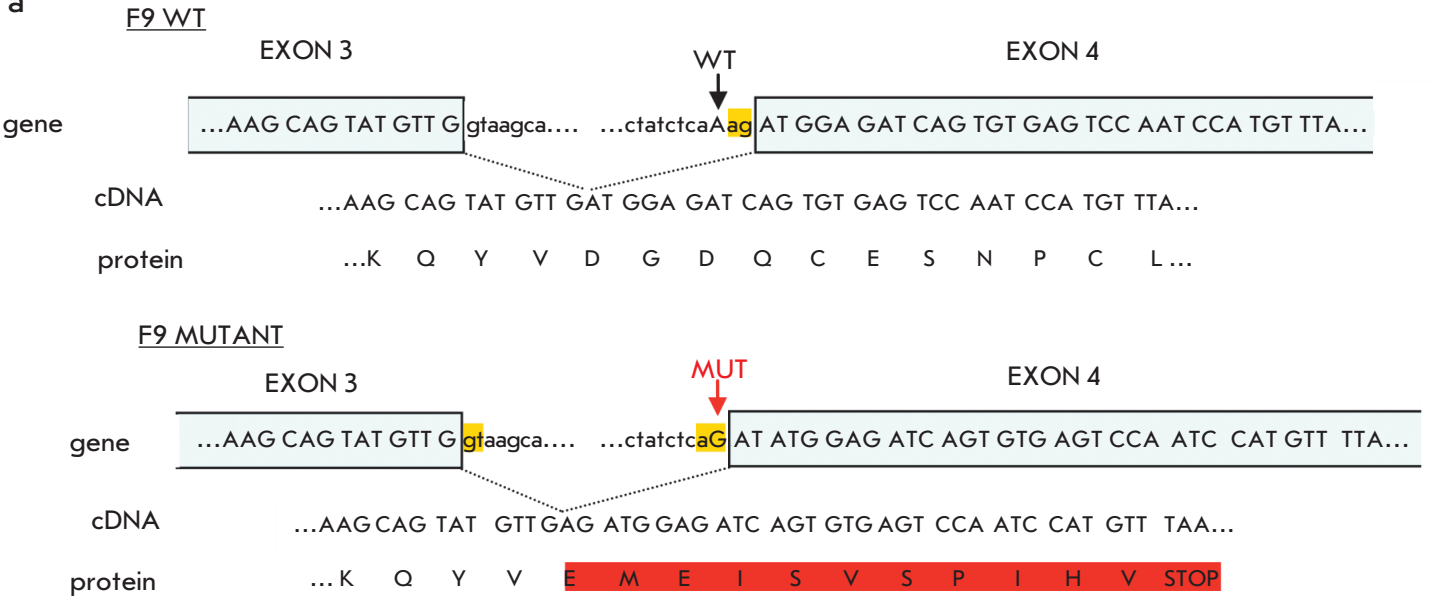

b

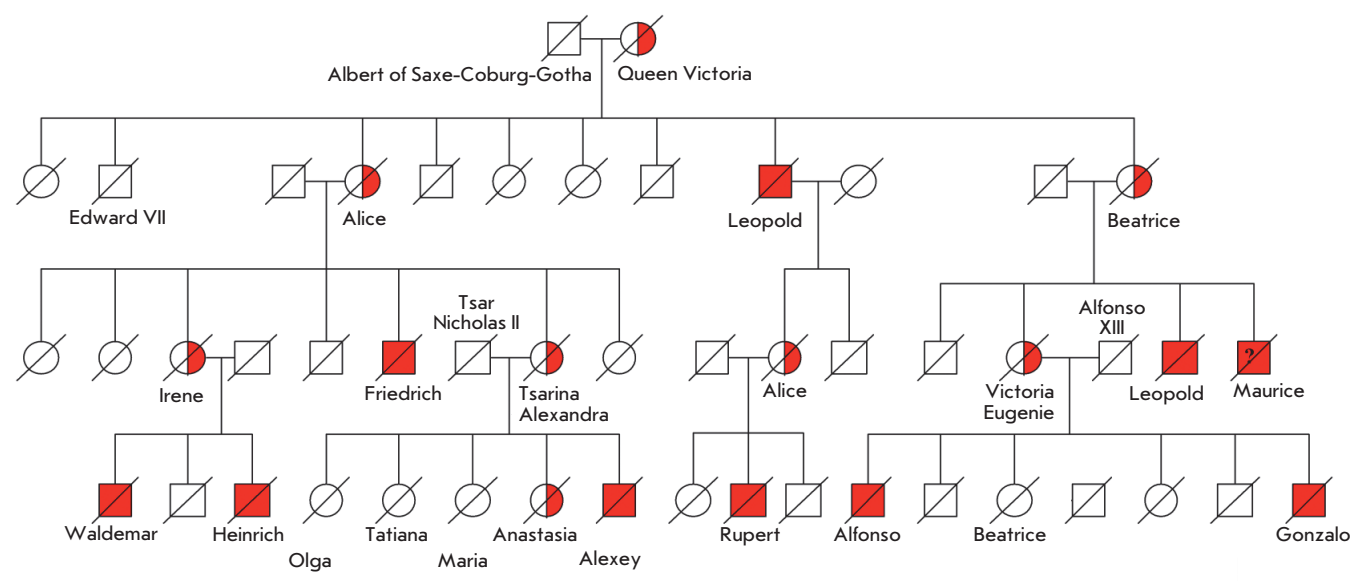

C

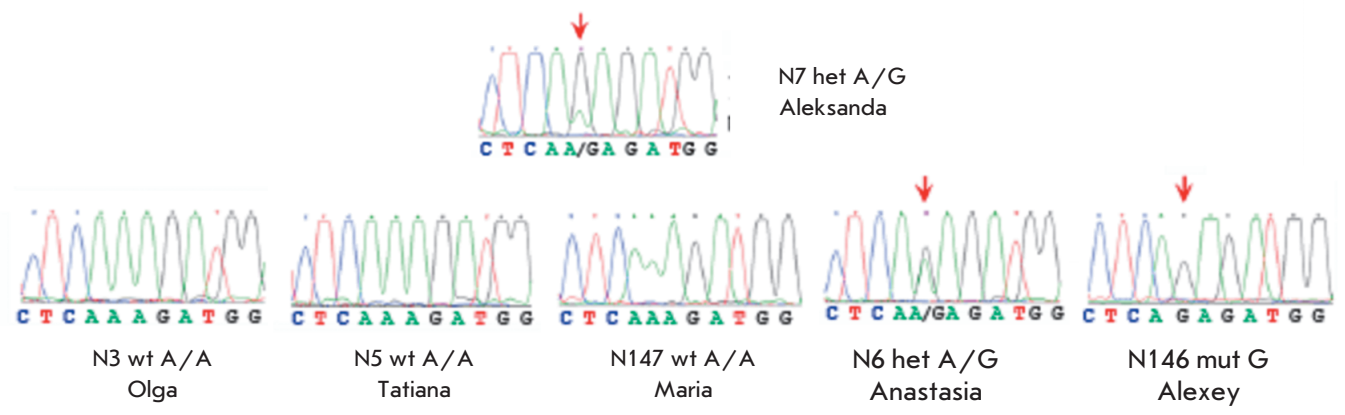

of a large cohort of unaffected individuals did not reveal any IVS3-3A $>$ G affected individuals, while we found three reported hemophilic patients with the same substitution in Hemophilia B databases (Table 4). All three had reduced activity of Factor IX ( $\leq 1 \%$ of normal activity) and manifested severe hemophilia symptoms. These data confirmed that the hereditary illness in Queen Victoria's lineage, including Prince Alexey, was a severe form of hemophilia B caused by a rare mutation in the F9 gene [49]. Since none of Queen Victoria's ancestors were known to have hemophilia, it can be assumed that this mutation was acquired de novo during gametogenesis in one of her parents.

\section{CONCLUSION}

The methods of DNA analysis developed and widely used in recent years allow experimental identification and reconstruction of DNA nucleotide sequences extracted from biological samples preserved for prolonged periods of time in natural conditions or have been subjected to DNA and its constituent molecules damage. The possibility of a successful study of such samples is provided by the use of novel sequencing strategies, novel methods for extracting and purifying DNA, specially equipped facilities, variety of control experiments, and additional methods of data analysis that prevent interpretation errors in the data. All this factors have contributed 


\section{REVIEWS}

to the extraction of genetic information from organisms that have disappeared tens of thousands of years ago, and to the reconstruction of evolutionary events, which was hitherto unachievable in experimental study. These findings opened new possibilities for precise molecular genetic analysis of severely damaged and decayed DNA, which has already raised the standard of applied procedures in forensic medicine. The results reviewed in this paper could not have been obtained without the development of novel DNA technologies that can now be incorporated into the everyday routines of fundamental and applied research, making them more reliable, fast and informative, as well as lowering costs.

The study was supported by the Russian Federal Agency for Science and Innovation (federal contract 02.512.11.2231) and

by the Program "Biodiversity" of Presidium of Russian Academy of Sciences.
REFERENCES

1. Higuchi R., Bowman B., Freiberger M., Ryder O.A., Wilson A.C. // Nature. 1984. 312 (5991). P. 282-284

2. Higuchi R.G., Wrischnik L.A., Oakes E. et al. // J. Mol. Evol. 1987. 25 (4). P. 283-287. 3. Pääbo S. // Nature. 1985. 314. P. 644-645.

4. Willerslev E., Cooper A. Ancient DNA. // Proc. Biol. Sci. 2005. 272 (1558). P. 3-16.

5. Poinar H.N., Höss M., Bada J.L., Pääbo S. // Science. 1996. 272 (5263). P. 864-866.

6. Smith C.I., Chamberlain A.T., Riley M.S. et al. // Nature. 2001. 410 (6830). P. 771-772.

7. Gilbert M.T., Wilson A.S., Bunce M. et al. // Curr. Biol. 2004. 14. P. R463-R464.

8. Shapiro B., Drummond A.J., Rambaut A. et al. // Science. 2004. 306 (5701). P. 1561-1565. 9. Willerslev E., Hansen A.J., Brand T.B. et al. // Science. 2003.300 (5620). P. 792-795.

10. Willerslev E., Hansen A.J., Brand T.B. et al. // Curr. Biol. 2004.14 (1). P. R9-R10.

11. Barnes I., Matheus P., Shapiro B., Jensen D., Cooper A. // Science. 2002. 295. P. 2267-2270.

12. Lambert D.M., Ritchie P.A., Millar C.D. et al. // Science. 2001. 295 (5563). P. 2270-2273 13. Rogaev E.I., Moliaka Y.K., Malyarchuk B.A. et al. // PLoS Biol. 2006. 4 (3). P. e73.

14. Saiki R.K., Scharf S., Faloona F. et al. // Science. 1985. 230 (4732). P. 1350-1354.

15. Mullis K., Faloona F., Scharf S. et al. // Cold Spring Harb Symp Quant Biol. 1986. 51 Pt 1. P. $263-373$.

16. Saiki R.K., Gelfand D.H., Stoffel S. et al. // Science. 1988. 239 (4839). P. 487-491. 17. Pääbo S., Poinar H., Serre D. et al. // Annu. Rev. Genet. 2004. 38. P. 645-679. 18. Ho S.Y., Gilbert M.T. Ancient mitogenomics. // Mitochondrion. 2010.10 (1). P. 1-11. 19. Ramakrishnan U., Hadly E. A. // Mol Ecol. 2009.18 (7). P. 1310-1330. 20. Hofreiter M., Stewart J. // Curr Biol. 2009. 19 (14). P. R584-R594. 21. Woodward S.R., Weyand N.J., Bunell M. // Science. 1994. 266 (5188). P. 1229-1232. 22. Collura R.V., Stewart C.B. // Nature. 1995. 378 (6556).P. 485-489. 23. Cooper A., Wayne R. // Current Opinion in Biotechnology. 1998. 9. P. 49-53. 24. Noonan J.P., Coop G., Kudaravalli S. et al. // Science. 2006. 314 (5802). P. 1113-1118. 25. Green R.E., Krause J., Ptak S.E. et al. // Nature. 2006.444 (7117). P. 330-336 26. Wall J.D., Kim S.K. // PLoS Genet. 2007. 3 (10). P. 1862-1866.

27. Green R.E., Malaspinas A.S., Krause J. et al. // Cell. 2008.134 (3). P. 416-426. 28. Pennisi E. // Science. 2009. 323 (5916). P. 866-871.
29. Krings M., Stone A., Schmitz R.W. et al. // Cell. 1997. 90. P. 19-30.

30. Schmitz R.W., Serre D., Bonani G. Et al. // Proc. Natl. Acad. Sci. USA. 2002.99 (20). P. $13342-13347$

31. Noonan J.P., Hofreiter M., Smith D. et al. // Science. 2005. 309 (5734). P. 597-599.

32. Poinar H.N., Schwarz C., Qi J. et al. // Science. 2006. 311 (5759). P.392-394.

33. Schwarz C., Debruyne R., Kuch M. et al. // Nucleic Acids Res. 2009. 37 (10). P. 3215-3129.

34. Cooper A., Poinar H.N. // Science. 2000. 289 (5482). P. 1139

35. Binladen J., Wiuf C., Gilbert M.T. et al. Assessing the fidelity of ancient DNA sequenc-

es amplified from nuclear genes. // Genetics. 2006. 172 (2). P. 733-741.

36. Endicott P., Sanchez J.J., Pichler I. et al. // BMC Genet. 2009. 10. P. 29.

37. Pusch C.M., Broghammer M., Nicholson G.J. et al. //Mol. Biol. Evol. 2004.21 (11) P. 2005-2011.

38. Gilbert M.T., Hansen A.J., Willerslev E. et al. // Am J. Hum. Genet. 2003.72 (1).

P. 48-61.

39. Lamers R., Hayter S., Matheson C.D. // J. Mol. Evol. 2009. 68 (1). P.40-55.

40. Krause J., Dear P.H., Pollack J.L. // Nature. 2006.439 (7077). P. 724-727.

41. Shendure J., Ji H. // Nat. Biotechnol. 2008.;6 (10). P. 1135-1145.

42. Gill P., Ivanov P.L., Kimpton C. et al. // Nat. Genet. 1994. 6 (2). P. 130-135.

43. Ivanov P.L., Wadhams M.J., Roby R.K. et al. // Nat. Genet. 1996. 12 (4). P. 417-420.

44. Rogaev E.I. Analysis of mitochondrial DNA of the alleged remains of Nicholas II and his nephew. // In.: "Repentance". Government commission materials: Moscow, 1998. P. 171-182.

45. Rogaev E.I., Grigorenko A.P., Moliaka Y.K. et al // Proc. Natl. Acad. Sci U S A. 2009a. 106 (13). P. 5258-5263.

46.Grigorenko A.P., Andreeva T.V., Rogaev E.I. // Medical Genetics. 2009.8 (4). P. 45-46 47. Irwin J.A., Saunier J.L., Niederstatter H. et al. // J. Mol. Evol. 2009.68. P. 516-527. 48. Wai T., Teoli D., Shoubridge E.A. // Nat. Genet. 2008. 40 (12). P. 1484-1488.

49. Rogaev E.I., Grigorenko A.P., Faskhutdinova G., Kittler E.L., Moliaka Y.K. // Science. 2009b. 326 (5954). P. 817.

50. White G.C., Rosendaal F., Aledort L.M. et al. // Thromb. Haemost. 2001.85 (3). P. 560 